УДК 656.225

\title{
УДОСКОНАЛЕННЯ ІНФОРМАЦЙНО-КЕРУЮЧОЇ СИСТЕМИ ЗАЛІЗНИЦЬ В УМОВАХ ІНТЕРОПЕРАБЕЛЬНОСТІ
}

Канд. техн. наук Т.Ю. Калашнікова, С.М. Кушкін, С.Д. Куценко СОВЕРШЕНСТВОВАНИЕ ИНФОРМАЦИОННО-УПРАВЛЯЮЩЕЙ СИСТЕМЫ
ЖЕЛЕЗНЫХ ДОРОГ В УСЛОВИЯХ ИНТЕРОПЕРАБЕЛЬНОСТИ

Канд. техн. наук Т.Ю. Калашникова, Е.М. Кушкин, Е.Д. Киценко

\section{IMPROVING INFORMATION MANAGEMENT SYSTEM OF RAILWAYS ON THE BASIS OF THE INTEROPERABILITY}

Cand. of techn. sciences T.Y. Kalashnikova, E.M. Kushkin, E.D. Kicenko

У статті досліджуються питання удосконалення інформаційно-керуючої системи залізниць в умовах інтероперабельності за рахунок формування дворівневої структури ІКС для управління функиіонування МТК на стратегічному та тактичному рівнях при взаємодї різних рівнів управління поїзопотоками краӥн-учасниць перевізного процесу.

Ключові слова: транспортна система, залізничний транспорт, інтероперабельність, інформаційно-керуюча система.

В статье исследуются вопросы совершенствования информационно-управляющей системь железных дорог в условиях интероперабельности за счет формирования двухуровневой структуры ИКС для управления функиионирования МТК на стратегическом и тактическом уровнях при взаимодействии различных уровней управления поездопотоками стран-участнии перевозочного прочесса.

Ключевые слова: транспортная система, железнодорожный транспорт, интероперабельность, информачионно-управляющая система

This research paper examines the issues of improving information management system (IMS) of railways in terms of interoperability due to the formation of a two-tier structure of the ICS to manage the operation of the IMS at the strategic and tactical levels between the different levels of government flows trains countries participating in the transportation process. It is proved that the implementation of the requirements of interoperability when using IMS allows flexible control technology flows trains international transport corridors through the basic tasks associated with the order or change the route of destination and bandwidth management.

Keywords: transport system, rail transport, interoperability, information management system.

Вступ і постановка проблеми у загальному вигляді та іiі зв'язок із важливими науковими та практичними завданнями. Залізничний транспорт України забезпечує перевезення більше 40 відсотків пасажирів та 50 відсотків вантажу від загальної кількості пасажиро- та вантажообігу країни. Зазначені обсяги розподіляються між внутрішніми та закордонними напрямками просування поїздопотоків [1]. При цьому в умовах просування вагоно- та поїздопотоків в межах держави технологія роботи залізничного транспорту повинна передбачати раціональну взаємодію між різними учасниками перевізного процесу для забезпечення вимог клієнтів щодо своєчасної та якісної доставки вантажів. При відправленні або прийманні вантажів на територію України, а також транзитного пропуску поїздів так званими міжнародними транспортними коридорами (МТК) постають питання взаємодії адміністрацій країн-учасниць перевізного процесу, які включають в себе нормативне та правове супроводження перевезень.

Визначення мети та задачі дослідження. Найбільш доцільним та 
перспективним варіантом вирішення задачі пошуку раціональних рішень щодо забезпечення техніко-технологічної та інформаційної сумісності як між Укрзалізницею та внутрішніми суміжними перевізниками, так i між Укрзалізницею та закордонними залізничними адміністраціями є створення інтероперабельних техніко-технологічних та інформаційних рішень щодо забезпечення перевізного процесу на внутрішньодержавних та міждержавних шляхах.

Відповідно до цього слід зазначити, що поїздопотік за своєю природою є непостійною величиною, тобто він може коливатися як у межах значного інтервалу часу (рік), так і в менших діапазонах (доба, декада, місяць...). Це у свою чергу вимагає вирішення питання стратегічного та оперативного планування (в залежності від часового інтервалу коливань поїздопотоку).

Аналіз останніх досліджень. Питаннями інформаційно-керуючих систем залізничного транспорту у різні часи займалися відомі вчені, такі як M.I. Данько, Т.В. Бутько, Д.В. Ломотько, А.М. Котенко та багато інших [1, 5, $8,9,10]$. Серед останніх робіт, присвячених цьому питанню, слід відзначити $[6,7]$.

\section{Основна частина дослідження.} Сформовану структурну схему інформаційнотехнологічної взаємодії відповідних відділів та служб Укрзалізниці 3 автоматизованими системами країн-учасниць перевізного процесу наведено на рис. 1. Глобально сформована схема розділена на два рівні - перший рівень відповідає за стратегічне планування функціонування i розвитку МТК, а другий рівень відповідає за оперативне управління поїздопотоками МТК. 3 метою дотримання техніко-технологічної та інформаційної сумісності на основі вимог інтероперабельності передбачено взаємодію першого та другого рівнів 3 комплексом автоматизованих робочих місць (АРМ) закордонних адміністрацій по роботі з МТK [3].

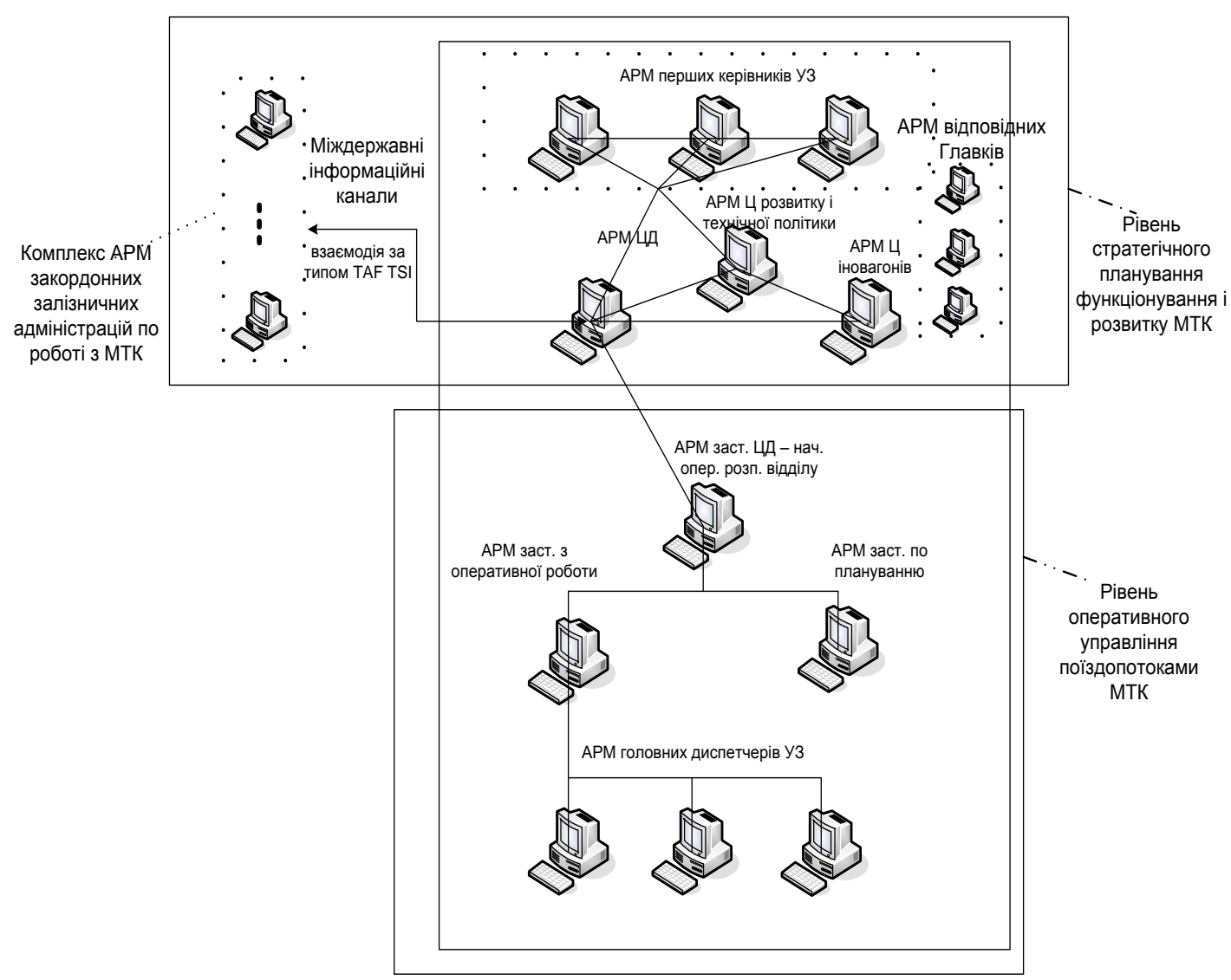

Рис.1. Структурна схема інформаційної взаємодії учасників МТК на основі вимог інтероперабельності 
Зв'язок АРМ закордонних залізничних адміністрацій по роботі МТК 3 АРМами ЦД (Головного управління перевезеннями) на рівні стратегічного планування повинен забезпечити перспективний розвиток (стратегічний) МТК, що проходять територією України. Тобто на основі прогнозних та реальних поїздопотоків буде визначатися необхідне технічне озброєння конкретних коридорів, а саме: кількість колій на дільницях, кількість головних та інших колій на залізничних станціях, електрифікація дільниць, необхідність обладнання дільниць сучасними пристроями диспетчерської централізації.

На рівні оперативного управління поїздопотоками МТК передбачається взаємодія АРМ закордонних залізничних адміністрацій 3 АРМ оперативно-розпорядчого відділу ЦД. Дана взаємодія передбачає застосування основних функціональних підзадач системи конвенційних залізниць, зокрема «Технічні специфікації прикладних програмних забезпечень для вантажних забезпечень - TAF TSI» $[4,5]$.

Таким чином, згідно 3 основними визначеними функціональними під задачами, доцільно навести більш детальну їх характеристику, яка буде відповідати існуючій технології роботи основних підрозділів залізничного транспорту України та Транс'європейської системи конвенційних залізниць [2]. Згідно з цим у всіх випадках перед початком процесу перевезення вантажу повинна бути сформована електронна накладна, яка містить дані, що надходять від клієнта до інтегратора послуг (LRU). Ці дані потрібні для перевезення вантажу від відправника до одержувача. LRU мусить доповнити ці дані додатковими інформаціями, які пов'язані 3 процесом, реалізованим на станції відправлення. Ці дані згруповано за категоріями учасників (маються на увазі залізничні підприємства різних країн - RU), які беруть участь у перевізному процесі (RU оператор, що відправляє вантаж, RU транзитний, RU - призначення). По суті, замовлення вагона - це початковий підбір інформації для накладної, яку слід надати всім $\mathrm{RU}$, включеним у транспортний ланцюг. Вона $\epsilon$ основою для замовлення на трасу. Замовлення вагона має містити інформацію, необхідну RU для здійснення перевезення вантажу до наступного пункту передачі його наступному RU. Тому його зміст залежить від ролі залізничного підприємства: RU Відправник, RU Транзитне, або RU Поставки (ORU, TRU, DRU).

Після того, як було сформовано накладну постає задача замовлення траси поїзда. Відповідно до цього потрібна чітка взаємодія всіх RU, які беруть участь у перевізному процесі у міждержавному сполученні. 3 цією метою запропоновано схему взаємодії диспетчерського апарату УЗ, яка забезпечить раціональне виконання під задач, пов'язаних 3 замовленням траси та просуванням поїзда, або до кінцевого одержувача, або до станції переходу (рис. 2) в умовах єдиного інформаційного середовища TAF TSI.

Таким чином, відповідно до обраної структури диспетчерський апарат повинен вирішувати загальномережеві завдання управління перевізним процесом і видавати рішення 3 оперативного планування, регулювання й технології управління в масштабі мережі залізниць, окремих іiї районів, міжнародних транспортних коридорів. Оперативно-розпорядницький відділ повинен організувати виконання планів перевезень поїздопотоків МТК залізницями, територією яких проходять міжнародні транспортні коридори, виконувати функції щодо замовлення та змінення траси поїзда згідно 3 діючим нормативним графіком руху поїздів. На основі аналізу ходу експлуатаційної роботи на МТК диспетчерський апарат оперативнорозпорядного відділу повинен розробляти відповідні пропозиції, оперативні вказівки й завдання керівникам дорожніх диспетчерських змін, а при необхідності - керівникам служб перевезень або залізниць [6,7].

Для забезпечення постійного моніторингу за складом поїзда формується комунікат - «склад поїзда». Цей комунікат RU мусить висилати до наступного RU, визначаючи склад поїзда. Цей комунікат треба також висилати до IM, коли його вимагає ОРЕ TSI, або контракт між IM та RU. Якщо під час подорожі відбулися будь-які зміни в складі поїзда, відправлене за цей відрізок перевезення IM та RU повинно цим комунікатом повідомити всіх включених у перевізний процес і надати актуального характеру змінам, що настали. 


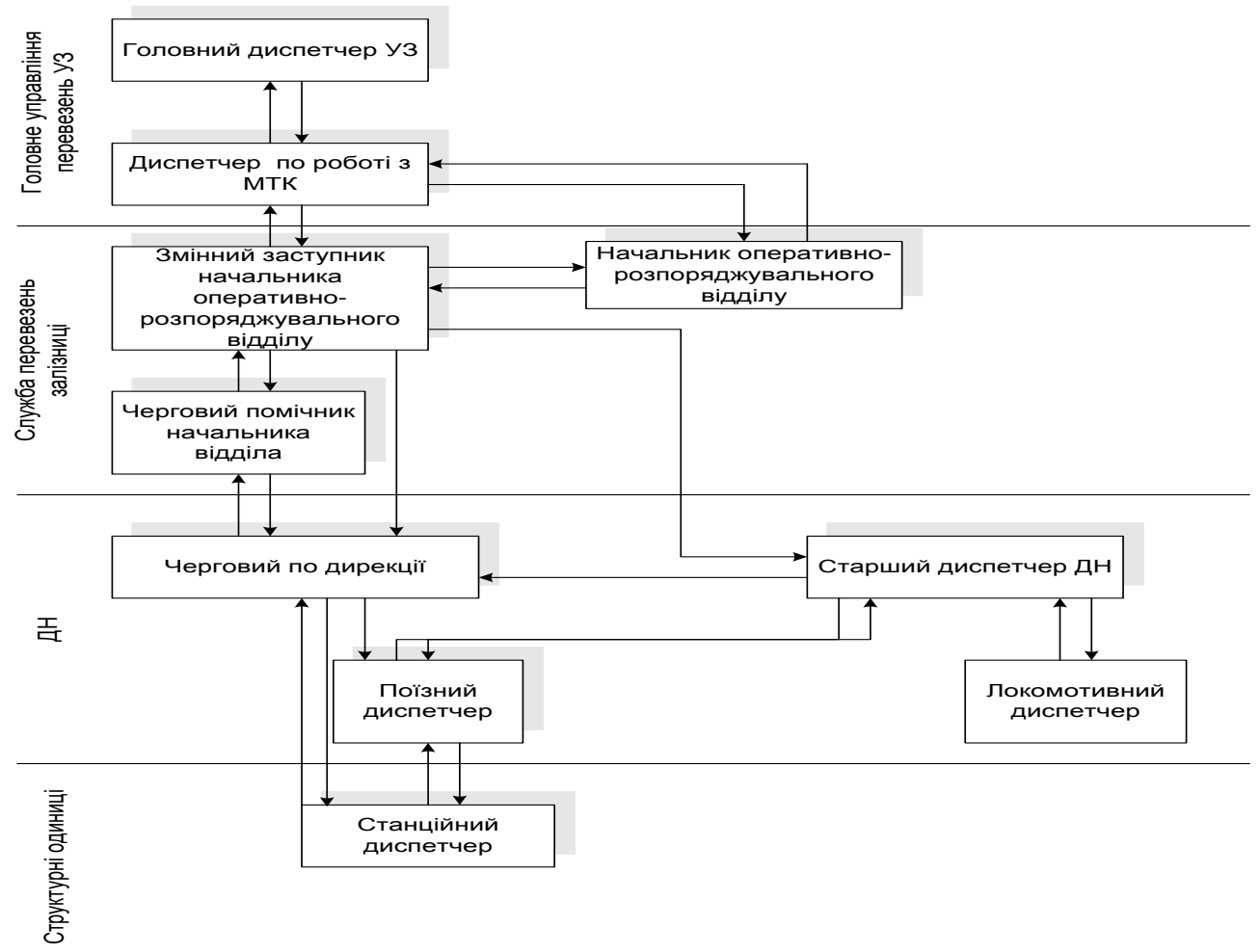

Рис. 2. Структурна схема управління поїздопотоками МТК

Перспективним напрямком забезпечення даного комунікату $є$ застосування системи глобального супутникового позиціювання GPS. Ця технологія дозволяє отримувати точні дані про місцезнаходження рухомої одиниці в реальному режимі часу (3 незначним відставанням), що надасть можливості найбільш оптимально реалізувати інтелектуальну систему стратегічного та оперативного планування просування поїздопотоків МТК.

TAF TSI створюють неповторну ситуацію для розвитку i інтеграції застосувань інформатики в міжнародних вантажних перевезеннях, яку не можна втратити. Кожне залізничне підприємство Європейського союзу, яке бере участь у міжнародному транспортному ланцюзі, може скористатися цією нагодою i залучитися до процесу створення, у першу чергу, «Стратегічного європейського плану ефективного застосування TAF TSI» - SEDP, a потім доопрацювання та інтеграції інформативних рішень. Спільне ведення робіт у рамках ЄC гарантує послідовну реалізацію передумов TAF TSI, згідно 3 коштами, що припадають на кожного з учасників.
Висновки 3 дослідження і перспективи, подальший розвиток у даному напрямку. Реалізація вимог інтероперабельності при реалізації ІКС дозволяє застосувати гнучку технологію управління поїздопотоками міжнародних транспортних коридорів шляхом вирішення основних задач, пов'язаних 3 замовленням або зміною траси прямування та управлінням пропускною спроможністю, в результаті чого досягається: зменшення експлуатаційних витрат на перевезення вантажів у межах МТК, прискорення доставки вантажів, забезпечення дотримання логістичних принципів при перевезеннях як в межах країни, так i y міждержавному сполученні, покращення виконання якісних та кількісних показників роботи Укрзалізниці.

Запропоновані моделі оперативного управління поїздопотоками міжнародних транспортних коридорів 3 точки зору інформаційного оформлення передбачають сумісність протоколів із Технічними специфікаціями прикладних програмних забезпечень для вантажних забезпечень - TAF TSI. 


\section{Список використаних джерел}

1. Бутько, Т.В. Планування перевезень вантажу на основі раціональної організації вагонопотоків на залізниці із застосуванням теорії нечітких множин [Текст] / Т.В. Бутько, О.В. Лаврухін // Східно-Свропейський журнал передових технологій. - 2004. - Спецвипуск 7 [1]. C. 16-19.

2. Акуленко, А.А. Застосування нормативів ЄС на українських напрямках міжнародних транспортних коридорів [Текст] / А.А. Акуленко // Залізн. трансп. України. - 2004. — № 5. - С. 8-9.

3. Козак, В.В. Интенсификация международных железнодорожных перевозок [Текст] / В.В. Козак // Залізн. трансп. України. - 2007. - № 2. - С. 3-4.

4. Козак, В.В. Формалізація системи міжнародних перевезень для вирішення проблеми актуалізації мережі транспортних коридорів [Текст] / В.В. Козак // Зб. наук. праць. - Харків: УкрДАЗТ, 2010. - Вип. 119. - С. 17-25.

5. Козак, В.В. Удосконалення технології обробки вантажопотоків в рамках Єдиної системи управління парком вантажних вагонів (ССУПВВ) [Текст] / В.В. Козак, М.I. Данько, Є.С. Альошинський, А.С. Смаглюк, О.О. Тремполець // Вагонный парк. - 2011. - № 6. - С. 12-17.

6. Козак, В.В. Формування моделі оперативного управління вагонопотоками у межах МТК за умови інтероперабельності транспортної системи [Текст] / В.В. Козак // Зб. наук. праць. - Донецьк: ДонІЗТ, 2011. - Вип. 26. - С. 5-12.

7. Козак, В.В. Удосконалення технології просування поїздопотоків залізницями України на основі інтероперабельності [Текст] / В.В. Козак, М.І. Данько // Восточно-Европейский журнал передових технологий. - 2011.- № 4/3(52).- С. 16-18.

8. Ломотько, Д.В. Удосконалення функціонування автоматизованої системи розподілу транспортних ресурсів на Харківській дирекції залізничних перевезень [Текст] / Д.В. Ломотько, А.О. Ковальов, О.В. Ковальова // Зб. наук. праць. - Харків: УкрДАЗТ, 2013. - Вип. 137. - С.5-11.

9. Котенко, А.М. Удосконалення інформаційної технології роботи 3 вагонами власності підприємств у АСК ВП УЗ [Текст] / А.М. Котенко, А.В. Кулешов, В.В. Кулешов // Зб. наук. праць. Харків: УкрДАЗТ, 2010. - Вип. 113. - С. 38-46.

10. Данько, М.І. Удосконалення функціональних можливостей автоматизованого аналізу стану технічних засобів в частині прийняття керівних рішень на умовах ресурсозбереження [Текст] / М.І. Данько, А.М. Котенко, В.В. Кулешов, А.В. Кулешов // Восточно-Европейский журнал передовых технологий. - 2009. - № 4/7(40). - С. 4-7.

Рецензент д-р техн. наук, професор О.М. Огар

Калашнікова Тетяна Юріївна, канд. техн. наук, доцент кафедри управління експлуатаційною роботою, Українська державна академія залізничного транспорту. Тел.: 057-730-10-88.

Кушкін Свгеній Миколайович, слухач групи МЗ-ОПУТ-Б12-ТЕД Української державної академії залізничного транспорту.

Кіценко Євген Дмитрович, студент групи 13-VI-ОПУТм Української державної академії залізничного транспорту.

Kalashnikova Tetiana Yuriyivna, Cand. of techn. sciences, associate professor of the chair "Management of operational work". Tel.:057-10-88

Kushkin Evgeniy Mikolayovich, student of the group M3-ROM-B12-TEW.

Kicenko Evgen Dmytrovich, student of the group 13- VI-ROMм. 